\title{
USE OF THE BIOSTIMULATION OF INDIGENOUS MICROBIAL COMMUNITIES TO DEGRADE TOTAL PETROLEUM HYDROCARBONS IN CONTAMINATED SOIL
}

\author{
GUTIÉRREZ-AlCÁNTARA, E. J. ${ }^{1}$ - TIRADO-TORRES, D. ${ }^{2 *}$ - VÁZQUEZ-RODRÍGUEZ, G. ${ }^{2}-$ \\ DELGADILlO-RUíz, E. ${ }^{2}$ - SALAZAR-HERNÁNDEZ, M. ${ }^{3}$ - RAMÍREZ-RAMÍREZ, N. ${ }^{4}-$ \\ ZAMORATEGUI-MOLINA, A. ${ }^{2}$ \\ ${ }^{1}$ Faculty of Chemical-Biological Sciences, Autonomous University of Campeche, Av. Agustin \\ Melgar S / N, Buena Vista, C.P: 24039, Campeche, Cam., Mexico \\ ${ }^{2}$ Department of Civil Engineering, Division of Engineering, Campus Guanajuato, University of \\ Guanajuato, Av. Juarez $N^{\circ}$ 77, Col. Centro, Guanajuato, Gto., Mexico \\ ${ }^{3}$ Department of Mines, Metallugy and Geology, Division of Engineering, Campus Guanajuato, \\ University of Guanajuato, Exhacienda de San Matias S/N Col. San Javier, Guanajuato, Gto., \\ Mexico \\ ${ }^{4}$ Department of Hydraulic and Geomatics Engineering, Division of Engineering, Campus \\ Guanajuato, University of Guanajuato, Av. Juarez No 77, Col. Centro, Guanajuato, Gto., \\ Mexico \\ *Corresponding author \\ e-mail:d.tirado@ugto.mx
}

(Received $13^{\text {th }}$ Jan 2019; accepted $8^{\text {th }}$ Mar 2019)

\begin{abstract}
This study examined the best option for remediating soil contaminated with crude oil through the addition of the inorganic nutrients $\mathrm{C}: \mathrm{N}: \mathrm{P}$ (yeast extract-glucose, $\mathrm{NH}_{4} \mathrm{Cl}-\mathrm{NaNO}_{3}$ and $\mathrm{K}_{2} \mathrm{HPO}_{4}-\mathrm{K}_{3} \mathrm{PO}_{4}$ ), in order to increase the degradation of TPHs in the soil. To the contaminated soil a physicochemical characterization was made to know the initial conditions of the inorganic nutrients. The controlled conditions in the biostimulation strategy were 20 days of incubation under uncontrollable ambient temperature conditions. Responses measured after the experiments were residual TPHs, surface tension, respiratory activity and microbial counting. After an incubation period of 20 days, the best treatments found were $\mathrm{Y} 5$, which contains the nutrient source glucose- $\mathrm{NaNO}_{3}-\mathrm{K}_{3} \mathrm{PO}_{4}$, and $\mathrm{Y} 4$ (yeast extract- $\mathrm{NH}_{4} \mathrm{Cl}$ $\mathrm{K}_{2} \mathrm{HPO}_{4}$ ), with degradation efficiencies of 14.0 and $12.8 \%$, respectively. Biostimulation with inorganic nitrogen and phosphorus increased the metabolic activity of indigenous microorganisms in the soil and thereby increased the degradation of petroleum hydrocarbons. The Y5 and Y4 treatments can be considered as suitable for use as a biostimulation strategy in soils contaminated with TPHs.
\end{abstract}

Keywords: bioremediation, inorganic nutrients, crude oil, soil remediation, bacterial population

\section{Introduction}

A vital raw material for the operation of industries and private businesses, oil has become the most important non-renewable resource for modern society (Costa et al., 2012). However, it is a potential source of pollution in the seas, soil and air (Liu et al., 2010), causing major environmental problems worldwide. The degradation of organic pollutants, such as petroleum hydrocarbons, is limited by the assimilation capacity of the native flora of the soil. In some cases, natural attenuation cannot sufficiently eliminate xenobiotics from the soil due to the potential effect of soil conditions, such as organic matter content, soil particle size and microbiota density (Abed et al., 2015). Bioremediation is a technique that uses the metabolism of microorganisms to transform 
hydrocarbons into $\mathrm{CO}_{2}$ and $\mathrm{H}_{2} \mathrm{O}$. It has been found that significant optimization of remediation parameters and increased microbial activity occur when strategies, such as biostimulation, are employed (Coulon et al., 2012).

This strategy entails the addition of nutrients to the indigenous community of microorganisms to incentivize metabolic action and improve the degradation of the pollutant being treated (Abed et al., 2014; Taccari et al., 2012). It should be noted that the application of this type of technique is recommended when the soil to be treated lacks the nutrients necessary for bioremediation. While bioaugmentation has resulted in higher rates of degradation in some cases (Ma et al., 2015; Taccari et al., 2012), the stimulation of indigenous microorganisms has resulted in the significant reduction of hydrocarbons in the soil (Suja et al., 2014; Silva et al., 2009). Thanks to biostimulation, groups of microorganisms native to the soil, such as archaebacteria, contribute directly or indirectly to the elimination of petroleum hydrocarbons (Ghoreishi et al., 2017; Ghosal et al., 2016). Therefore, in some cases, bioremediation mechanisms are stimulated by increasing the growth of indigenous hydrocarbon-degrading microorganisms (Milic et al., 2009); however, in others, remediation is ineffective as the degradation effect requires too much time (Couto et al., 2010; Bento et al., 2005) due to the lack of limiting nutrients that accelerate the remediation carried out by indigenous microorganisms (Atlas and Hazen, 2011).

Research on biostimulation has been conducted on indigenous microorganisms from different types of soil, with different sources of nutrients applied to improve microbial activity and degrade petroleum hydrocarbons (Abed et al., 2015; Hassanshahian et al., 2014; Taccari et al., 2012). However, this research was conducted on a tropical soil lacking nutrients and with a low density of indigenous microorganisms. Therefore, this study aimed to evaluate both the efficiency of total petroleum hydrocarbons (TPHs) degradation by applying biostimulation with the addition of various sources of nutrients (carbon, nitrogen and phosphorus) and the effect of the production of biosurfactants in the soil.

\section{Materials and methods}

\section{Selection of the study area and soil sampling}

Soil with a history of spills with petroleum hydrocarbons was collected in the municipality of Poza Rica, Veracruz, located at $20^{\circ} 32^{\prime \prime}$ north latitude and $97^{\circ} 27^{\prime \prime}$ west longitude, at an altitude of 50 m.a.s.l., at a depth of 5 at $40 \mathrm{~cm}$. Seven simple samples from different points in the contaminated site were collected, around $10 \mathrm{~kg}$ were taken per sample, the samples were collected before noon to avoid moisture loss and transported under shade. In the laboratory, all samples were mixed to form a composite sample. The soil is categorized as clay-sandy with conglomerate materials. The region has a warm climate, an average annual temperature of $24.2^{\circ} \mathrm{C}$, average annual precipitation of $1,010 \mathrm{~mm}$ and relative moisture of 76 to $80 \%$ (INEGI, 2015).

\section{Physicochemical characterization of the soil}

Different physicochemical parameters of the soil were taken to verify that it was a soil type viable for the application of biostimulation. Each parameter was taken in triplicates (Table 1). 
Table 1. Physical and chemical properties of the soil

\begin{tabular}{c|c|c}
\hline Parameter & Value & Method \\
\hline Moisture $(\%)$ & $32.64 \pm 0.46$ & Gravimetric \\
$\mathrm{pH}$ & $7.85 \pm 0.01$ & Potentiometric \\
Pensity $\left(\mathrm{g} / \mathrm{cm}^{3}\right)$ & $1.09 \pm 0.03$ & Pycnometer \\
Micro-Kjeldahl \\
Total nitrogen $(\%)$ & $0.25 \pm 0.00$ & Bray I \\
Assimilable phosphorous & $\mathrm{n} / \mathrm{d}$ & \\
(mg/kg) & $11.14 \pm 0.26$ & Oxidation with chromic acid \\
Organic matter $(\%)$ & Clay-sandy sulphuric acid \\
Texture & $50,000 \pm 852$ & Hydrometer \\
TPHs (mg/kg) & $1.04 \times 10^{4} \pm 3.21 \times 10^{2}$ & Gravimetric \\
Total bacteria (CFU) & $1.06 \times 10^{3} \pm 3.06 \times 10^{1}$ & CFUs \\
Total fungi (CFU) & & CFUs \\
\hline
\end{tabular}

Note: $\mathrm{n} / \mathrm{d}$ : not detected, \pm : standard deviation.

The characterization of the contaminated soil revealed an unfavorable proportion between the main nutrients, namely nitrogen and phosphorus. According to Tindal (2005), the TPHs content shows that this a highly contaminated soil, with a slightly alkaline $\mathrm{pH}$ and a moisture content close to $30 \%$. The presence of petroleum hydrocarbons causes higher proportions of $\mathrm{C}$, resulting in a deficiency of both $\mathrm{N}$ and $\mathrm{P}$ (Atlas and Hazen, 2011). According to Abed et al. (2014), the concentration of indigenous microorganisms is low due to the $\mathrm{N}$ and $\mathrm{P}$ deficiency, as these nutrients are limiting factors in the growth of microorganisms. Given the low microbial mass, it was decided to apply nutrients to the soil in order to increase both microbial density and the degradation of TPHs.

\section{Experimental development}

From the composite sample we proceeded to make an experimental design of $2^{3}$ (Table 2), they were taken $2 \mathrm{~kg}$ of soil in wet base and placed in trays.

Table 2. Representation of factors and levels, the experimental matrix for the $2^{3}$ factorial design, the experimentation plan, and the responses measured

\begin{tabular}{|c|c|c|c|c|c|c|c|}
\hline \multicolumn{6}{|c|}{ Factors (Independent Variables) } & \multirow{2}{*}{\multicolumn{2}{|c|}{$\begin{array}{c}\text { Levels } \\
+1 \\
\left(\mathrm{~g} \cdot \mathrm{kg}^{-1}\right)\end{array}$}} \\
\hline \multicolumn{4}{|c|}{ Sources of: } & \multicolumn{2}{|c|}{$\begin{array}{c}-1 \\
\left(\mathrm{~g} . \mathrm{kg}^{-1}\right)\end{array}$} & & \\
\hline \multicolumn{4}{|c|}{$\begin{array}{c}\mathrm{X}_{1}: \text { Source of carbon } \\
\mathrm{X}_{2}: \text { Source of nitrogen } \\
\mathrm{X}_{3}: \text { Source of phosphorous }\end{array}$} & \multicolumn{2}{|c|}{$\begin{array}{l}\text { Glucose (13.6) } \\
\mathrm{NaNO}_{3}(5.0) \\
\mathrm{K}_{2} \mathrm{HPO}_{4}(2.0)\end{array}$} & \multicolumn{2}{|c|}{$\begin{array}{c}\text { Yeast extract (0.01) } \\
\mathrm{NH}_{4} \mathrm{Cl}(1.0) \\
\mathrm{K}_{3} \mathrm{PO}_{4}(0.2) \\
\end{array}$} \\
\hline \multicolumn{4}{|c|}{ Experiment matrix } & \multicolumn{2}{|c|}{ Experimentation plan } & \multicolumn{2}{|c|}{ Response } \\
\hline Treatment & $\mathbf{X}_{1}$ & $\mathbf{X}_{2}$ & $\mathbf{X}_{3}$ & Source of carbon & $\begin{array}{c}\text { Source of } \\
\text { nitrogen }\end{array}$ & $\begin{array}{c}\text { Source of } \\
\text { phosphorous }\end{array}$ & \\
\hline 1 & - & - & - & Glucose & $\mathrm{NaNO}_{3}$ & $\mathrm{~K}_{2} \mathrm{HPO}_{4}$ & $\mathrm{Y}_{1}$ \\
\hline 2 & + & - & - & Yeast extract & $\mathrm{NaNO}_{3}$ & $\mathrm{~K}_{2} \mathrm{HPO}_{4}$ & $\mathrm{Y}_{2}$ \\
\hline 3 & - & + & - & Glucose & $\mathrm{NH}_{4} \mathrm{Cl}$ & $\mathrm{K}_{2} \mathrm{HPO}_{4}$ & $\mathrm{Y}_{3}$ \\
\hline 4 & + & + & - & Yeast extract & $\mathrm{NH}_{4} \mathrm{Cl}$ & $\mathrm{K}_{2} \mathrm{HPO}_{4}$ & $\mathrm{Y}_{4}$ \\
\hline 5 & - & - & + & Glucose & $\mathrm{NaNO}_{3}$ & $\mathrm{~K}_{3} \mathrm{PO}_{4}$ & $\mathrm{Y}_{5}$ \\
\hline 6 & + & - & + & Yeast extract & $\mathrm{NaNO}_{3}$ & $\mathrm{~K}_{3} \mathrm{PO}_{4}$ & $\mathrm{Y}_{6}$ \\
\hline 7 & - & + & + & Glucose & $\mathrm{NH}_{4} \mathrm{Cl}$ & $\mathrm{K}_{3} \mathrm{PO}_{4}$ & $\mathrm{Y}_{7}$ \\
\hline 8 & + & + & + & Yeast extract & $\mathrm{NH}_{4} \mathrm{Cl}$ & $\mathrm{K}_{3} \mathrm{PO}_{4}$ & $\mathrm{Y}_{8}$ \\
\hline 9 & \multicolumn{3}{|c|}{ Not } & \multirow{2}{*}{\multicolumn{3}{|c|}{$\begin{array}{l}\text { Contaminated soil sterilized } \\
\text { Soil with natural attenuation }\end{array}$}} & $\mathrm{C}_{1}$ \\
\hline 10 & & Not & & & & & $\mathrm{C}_{2}$ \\
\hline
\end{tabular}


The experimental design consists of 8 biostimulation treatments with different nutrients in order to obtain the best combination and apply to a bioremediation process of the sampling site. In addition, two controls ( $\mathrm{C} 1$ and $\mathrm{C} 2$ ) were added, $\mathrm{C} 1$ contained contaminated soil sterilized and $\mathrm{C} 2$ was prepared with the same soil without addition of nutrient alone with the native microflora. For each treatment three replicates were made. The selection of inorganic nutrients was made according to Hassanshahian et al. (2014), with some modifications. The controllable parameters were: 20 days of incubation; humidity at 30\%; and, soil contaminated with $50,000 \mathrm{mg} / \mathrm{kg}$ of $\mathrm{TPHs}$, placing the samples under shade. The uncontrollable conditions in this work were the temperature that was presented throughout this design being of an average within 20 days of $30 \pm 3$ ${ }^{\circ} \mathrm{C}$. The response variables that were measured after treatment were residual TPHs, surface tension, respiratory activity and the number of colony forming units (CFU) of microorganisms.

\section{Measurement of response variables}

\section{Determination of TPHs}

The extraction of TPHs from the soil was carried out according to Dias et al. (2012), with some modifications. In a conical centrifuge tube, to which $1 \mathrm{~g}$ of moisture base soil, $2 \mathrm{~g}$ of Na2SO4 and $10 \mathrm{ml}$ of dichloromethane were added, mixed and vortexed for 45 seconds, and then centrifuged at $6,000 \mathrm{rpm}$ for 15 minutes. This procedure was repeated 3 times for each sample and the supernatant was then collected and concentrated in a rotavapor at $740 \mathrm{mbar}$ and $40^{\circ} \mathrm{C}$ until a volume of $2 \mathrm{ml}$ was obtained. Once the extract had been concentrated, it was analyzed in both a Thermo Scientific Nicolet 380 FT-IR and a Smart Orbit spectrophotometer. Given the complex matrix of the soil, its extraction efficiency was evaluated, with a concentration of 2fluorobiphenyl added to the soil prior to carrying out of the TPH extraction process.

\section{Surface tension}

The surface tension was measured using the hanging drop method in a model 200-00 Standard Goniometer with DROPimage Standard software (Ramé-Hart Instrument Co., EEUU) and Young-Laplace software, which is used to describe the shape of the drop under equilibrium conditions (Berry et al., 2015).

\section{Respitatory activity $\left(\mathrm{CO}_{2}\right)$}

$\mathrm{CO}_{2}$ evolution was measured using a Gow-Mac series 580 gas chromatograph, with an Alltech concentric column (CTR1) and a thermal conductivity detector coupled to a computer analyzing the samples via the Primary Computing Integration (CPI) Chromatography Data System program, version 6. The results were expressed as a percentage of $\mathrm{CO}_{2}$. The working conditions of the system were as follows: $100^{\circ} \mathrm{C}$ detector; $30^{\circ} \mathrm{C}$ column; $40^{\circ} \mathrm{C}$ injector; $125 \mathrm{mV}$ detector current; Helium as a mobile phase; $55 \mathrm{ml}$.min-1 flow for the mobile phase; and, $40 \mathrm{lb} / \mathrm{in}^{2}$ pressure for the mobile phase.

\section{Microbial count}

For the microbial count, nutrient agar was used for bacteria (Bioxón, México) and rose bengal agar (Disco, USA) for fungi. The microorganism count was assessed by 
applying the plate count method on the CFUs, in which $1 \mathrm{~g}$ of soil was weighed and diluted in $9 \mathrm{ml}$ of sterile saline water $(0.9 \% \mathrm{NaCl}$ w/v $)$. A series of successive $1 \mathrm{ml}$ dilutions were made in $9 \mathrm{ml}$ of sterile distilled water $\left(10^{1}\right.$ to $\left.10^{8}\right)$ from the colloidal suspension obtained, with each dilution stirred before the subsequent dilution, and with each dilution inoculated in triplicates. The samples inoculated for bacteria growth were incubated at $37^{\circ} \mathrm{C}$ for 48 to 72 hours, while the Petri dishes inoculated for fungal growth were incubated at $28^{\circ} \mathrm{C}$ for 7 days in the dark (Gong, 2012).

\section{Statical analysis}

The data were analyzed to detect significant differences $(\mathrm{P}<0.05)$ among the treatments, using one-way analysis of variance (ANOVA). Minitab version 18 software was used to carry out the statistical analysis. The means were compared using LSD and Tukey tests.

\section{Results and discussion}

\section{Removal of TPHs}

The initial concentration of TPHs for all treatments was $50,000 \mathrm{mg} / \mathrm{kg}$. Figure 1 shows the results obtained for the removal of TPHs via the different treatments used in the experimental design, with their respective controls $(\mathrm{C} 1$ : contaminated sterile soil; and, C2: natural attenuation). A decrease in non-significant TPHs was observed for C1, representing a loss of contaminant via chemical oxidation. C2 represents the soil with native flora, in which treatment a very minimal degradation rate was observed after 20 days of incubation, which is due to the low concentration of indigenous microorganisms present in the soil and the scarcity of nutrient sources. After an incubation period of 20 days, it was observed that the best treatments for the removal of TPHs were Y5> Y4= Y3, with residual concentrations of 43,000> 43,666 and 44,000 mg/kg, respectively.

The LSD and Tukey statistical tests show significant differences among the treatments $(\mathrm{P} \leq 0.05)$, with the best TPH degradation percentage obtained being 12 to $14 \%$ in 20 days. These results coincide with $\mathrm{Wu}$ et al. (2016), who obtained 23.45 and $28.26 \%$ TPHs removal in bioaugmented and biostimulated systems, respectively, with an initial concentration of $46,000 \mathrm{mg} / \mathrm{kg}$. This shows that the addition of inorganic nutrients such as $\mathrm{N}$ and $\mathrm{P}$ improve the action of indigenous microorganisms taken from contaminated soils and optimize the efficiency of soil remediation (Nikolopoulou and Kalogerakis, 2010). Stimulating the populations of indigenous microorganisms is vital for efficient TPHs degradation because the process requires many different bacterial species, as one single species is not capable of metabolizing more than two classes of compounds, in this instance hydrocarbons (Wu et al., 2013). Karamaladis et al. (2010), achieved $51.5 \%$ TPHs degradation, obtaining a concentration of 34,000 mg/kg after 20 days of incubation. This result is caused by the fact that lower concentrations of TPHs lead to the degradation of contaminants at a higher level (Sharma, 2012), which, in turn, generates a less toxic habitat for indigenous microorganisms and, thus, leads to higher microbial density and improved TPHs degradation (Wu et al., 2013). The results obtained here via biostimulation are significant compared to natural attenuation, which may be due to the $\mathrm{C}$ : $\mathrm{N}$ : $\mathrm{P}$ adjustment applied in this research, which stimulates both microbial growth and TPH degradation (Atlas and Hazen, 2011). This is consistent with previous studies, which found that the biostimulation of a soil contaminated with TPHs 
obtained superior results than bioaugmentation (Abed et al., 2014; Taccari et al., 2012; Kauppi et al., 2011).

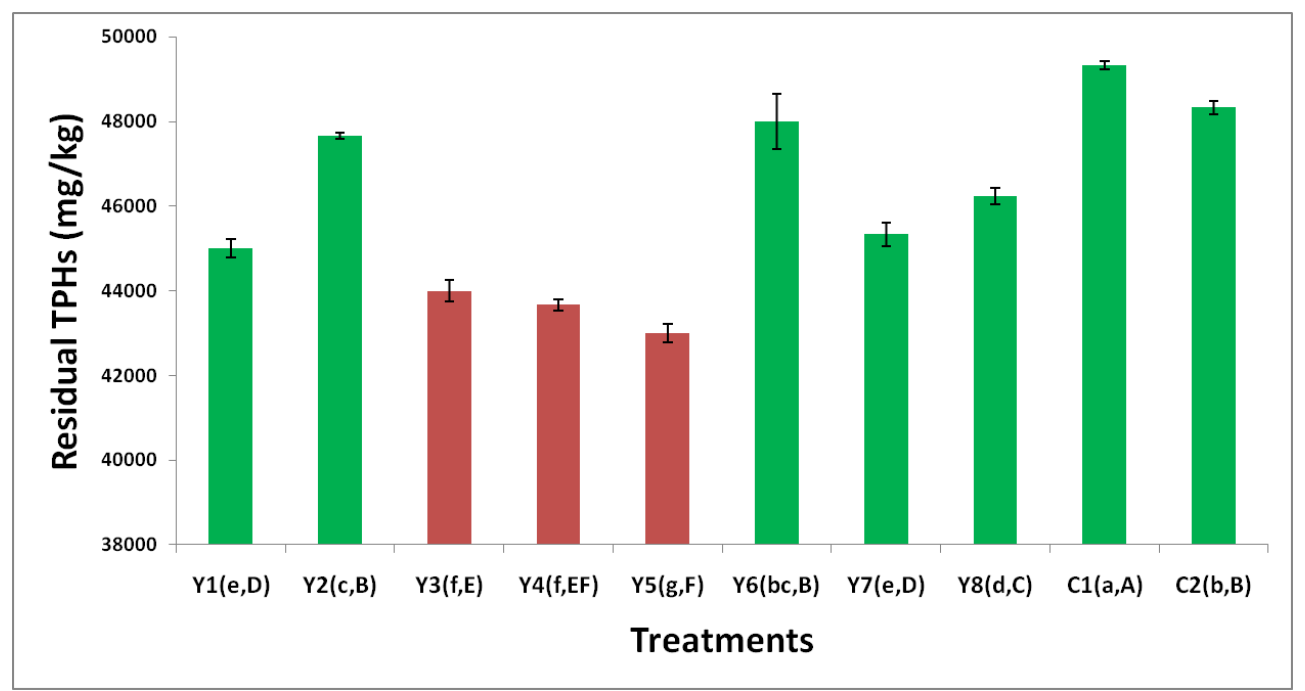

Figure 1. Removal of soil TPHs by applying the different biostimulation treatments. $(a, A)$ : Uppercase and lowercase letters within the parentheses correspond to the LSD and Tukey tests, respectively, $(P \leq 0.05)$. The dark red bars show treatments with significant degradation of TPHs

\section{Production of biosurfactants}

The presence of biosurfactants was analyzed by means of the change in the surface tension of the extract in the soils using an extracting solution, the surface tension of which was measured and it was considered as the initial tension of the systems as well as the medium of culture of $72.30 \mathrm{mN} / \mathrm{m}$ at a temperature of $25^{\circ} \mathrm{C}$ according to Soares et al. (2017). Figure 2 shows the significant differences found for the treatments with respect to the surface tension values obtained $(\mathrm{P} \leq 0.05)$.

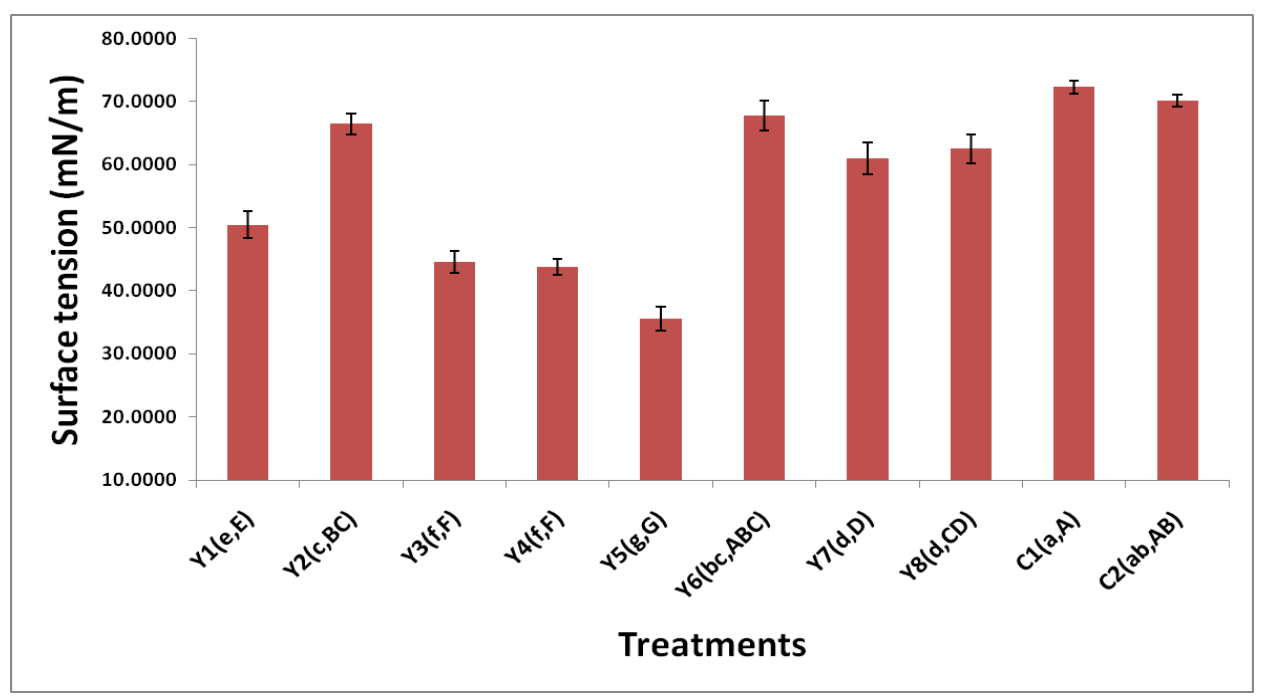

Figure 2. Surface tension in the different biostimulation treatments. (a,A): Uppercase and lowercase letters within the parentheses correspond to the LSD and Tukey tests, respectively $(P \leq 0.05)$. Culture medium $\gamma=72.30 \mathrm{mN} / \mathrm{m}$ at $25^{\circ} \mathrm{C}$ 
The LSD and Tukey tests show that there are significant differences between treatments $(\mathrm{P} \leq 0.05)$, with the treatments with the greatest surface tension change found to be $\mathrm{Y} 5>\mathrm{Y} 4=\mathrm{Y} 3$, with $35.63>43.82$ and $44.50 \mathrm{mN} / \mathrm{m}$, respectively. These changes in surface tension confirm the production of biosurfactants by indigenous flora (Lin et al., 2009). The decrease in surface tension also has a direct relationship with the removal of TPHs, as it indicates a higher level of biosurfactant production, which enables the increased availability of petroleum hydrocarbons, thus generating a higher level of TPHs degradation.

\section{Metabolic activity}

This The metabolic activity of the microbial community was measured by the production of $\mathrm{CO}_{2}$, with each treatment measured on days $1,3,5,10,15$ and 20 . The results obtained are shown in Figure 3 and reveal variable respiratory activity across all treatments. The results show an active microbial community (Diploick et al., 2009), while the treatments with the highest $\mathrm{CO}_{2}$ production level were $\mathrm{Y} 5=\mathrm{Y} 4>\mathrm{Y} 3$, a finding which is directly related to the study of biosurfactant production and TPHs degradation.

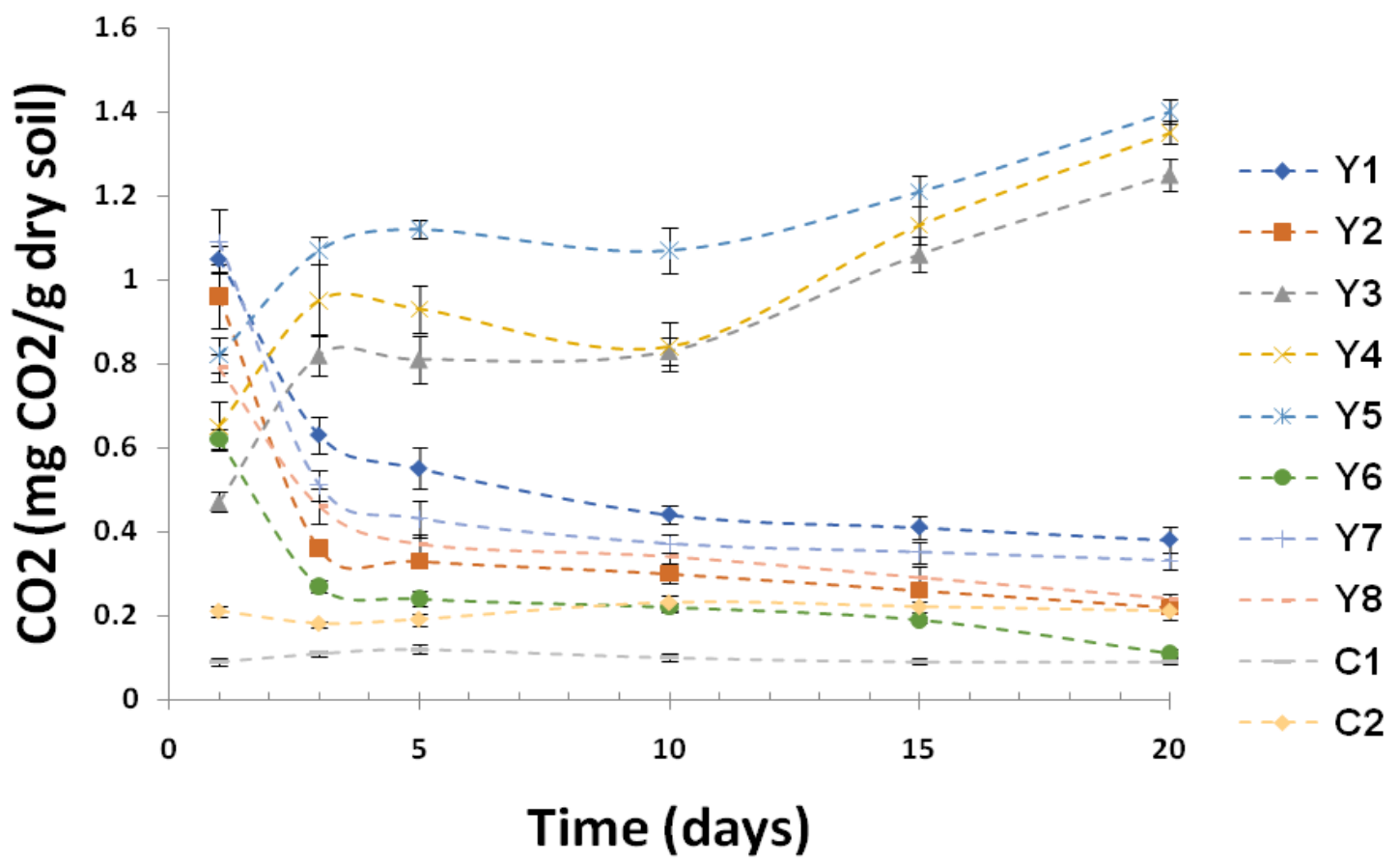

Figure 3. Release of $\mathrm{CO}_{2}$ over 20 days of incubation

To verify that the production was caused by the action of the microbial community, a count of microorganisms was performed, which again found that the Y5 $=\mathrm{Y} 4>\mathrm{Y} 3$ treatments had a higher microorganism population density, ranging from 6.36 to $9.83 \mathrm{x}$ $10^{7} \mathrm{CFU}$, compared to the initial concentration shown in Table 1 (1.04 x $\left.10^{4} \mathrm{CFU}\right)$ (Figure 4).

This proves not only that the bacterial populations were benefited by biostimulation with nutrients, but also that the populations of fungi presented greater population growth. Moreover, this study has observed a synergy effect between the bacterial and fungal populations, which improves the degradation of TPHs. 


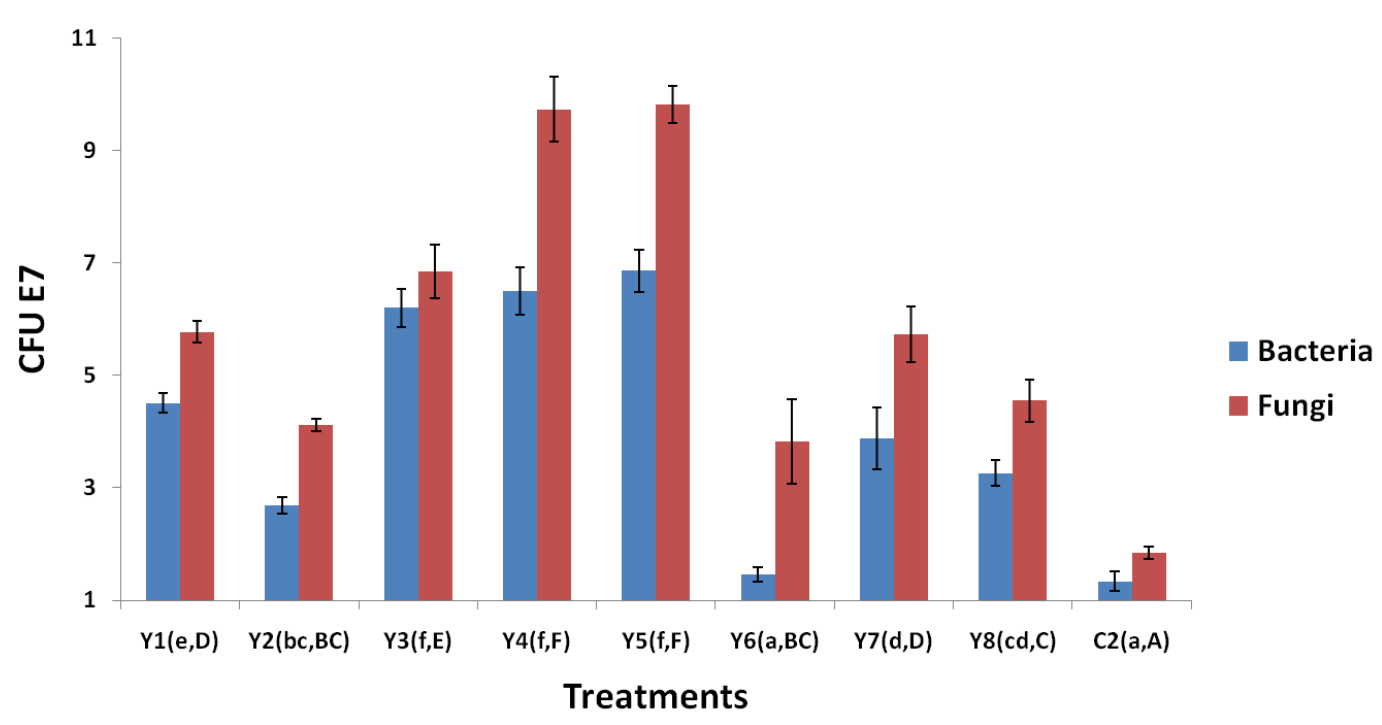

Figure 4. CFU of fungi and bacteria for each treatment in a biostimulated system

\section{Conclusions}

Based on previously obtained results with contaminated tropical soils, we can conclude that the success of bioremediation strategies depends on the properties of the contaminants, the nature of the nutrient products and the characteristics of the environment. Although several previous studies demonstrated the effectiveness of biostimulation, the present work could not demonstrate this fact since it took longer incubation time to be able to achieve a wider margin of degradation. Although in general, the treatments $\mathrm{Y} 5\left(\right.$ Glucose- $\left.\mathrm{NaNO}_{3}-\mathrm{K}_{3} \mathrm{PO}_{4}\right)$ and $\mathrm{Y} 4$ (yeast extract- $\mathrm{NH}_{4} \mathrm{Cl}-$ $\mathrm{K}_{2} \mathrm{HPO}_{4}$ ) proved to be more effective than the other treatments to stimulate the degradation of the hydrocarbon. In this particular situation, the biostimulation strategy evidenced a better performance of the natural bacterial community, which constitutes a promising alternative for the restoration of tropical soil contaminated with hydrocarbons.

Acknowledgements. This project was financially supported by Programa para el Desarrollo Profesional Docente (PRODEP), NPTC- 2018, grant number 511-6/18-8876, Secretaría de Educación Pública (SEP). To University of Guanajuato for the availability of its infrastructure.

\section{REFERENCES}

[1] Abed, R. M. M., Al-Kharusi, S., Al-Hinai, M. (2015): Effect of biostimulation, temperature and salinity on respiration activities and bacterial community composition in an oil polluted desert soil. - Int. Biodeterior. Biodeg. 98: 43-52. Available at: https://doi.org/10.1016/j.ibiod.2014.11.018.

[2] Abed, R. M. M., Al-Sabahi, J., Al-Maqrashi, F., Al-Habsi, A., Al-Hinai, M. (2014): Characterization of hydrocarbon-degrading bacteria isolated from oil-contaminated sediments in the Sultanate of Oman and evaluation of bioaugmentation and biostimulation approaches in microcosm experiments. - Int. Biodeterior. Biodeg. 89: 5866. Available at: https://doi.org/10.1016/j.ibiod.2014.01.006. 
[3] Atlas, R. M., Hazen, T. C. (2011): Oil biodegradation and bioremediation: a tale of the two worst spills in U.S. History. - Environ. Sci. Technol. 45(16): 6709-6715. Available at: https://pubs.acs.org/doi/abs/10.1021/es2013227.

[4] Bento, F. M., Camargo, F. A., Okeke, B. C., Frankenberger, W. T. (2005): Comparative bioremediation of soils contaminated with diesel oil by natural attenuation, biostimulation and bioaugmentation. - Bioresour. Technol. 96: 1049-1055. Available at: https://doi.org/10.1016/j.biortech.2004.09.008.

[5] Berry, J. D., Neeson, M. J., Dagastine, R. R., Chan, D. Y. C., Tabor, R. F. (2015): Measurement of surface and interfacial tensión using pendant drop tensiometry. - J. Colloid and Interface Sci. 454: 226-237. Available at: http://dx.doi.org/10.1016/j.jcis.2015.05.012.

[6] Costa, A., Romao, L., Araújo, B., Lucas, S., Maciel, S., Wisniewski, A., Alexandre, M. D. R. (2012): Environmental strategies to remove volatile aromatic fractions (BTEX) from petroleum industry wastewater using biomass. - Bioresour. Technol. 105: 31-39. Available at: https://doi.org/10.1016/j.biortech.2011.11.096.

[7] Coulon, F., Brassington, K. J., Bazin, R., Linnet, P. E., Thomas, K. A., Mitchell, T. R., Lethbridge, G., Smith, J. W. N., Pollard, S. J. T. (2012): Effect of fertilizer formulation and bioaugmentation on biodegradation and leaching of crude oils and refined products in soils. - Environ. Technol. 33: 1879-1893. Available at: https://doi.org/10.1080/09593330.2011.650221.

[8] Couto, M. N. P., Monteiro, E., Vasconcelos, M. T. S. (2010): Mesocosm trials of bioremediation of contaminated soil of a petroleum refinery: comparison of natural attenuation, biostimulation and bioaugmentation. - Environ. Sci. Pollut. Res. 17: 13391346. Available at: https://doi.org/10.1007/s11356-010-0318-y.

[9] Dias, R. L., Ruberto, L., Hernández, E., Vázquez S. C., Lo Balbo, A., Del Panno, M. T., Mac Cormack, W. P. (2012): Bioremediation of an aged diesel oil-contaminated Antartic soil: Evaluation of the "on site" biostimulation strategy using different nutrient sources. Int. Biodeterior. Biodegr. 75: 96-103. Available at: http://dx.doi.org/10.1016/j.ibiod.2012.07.020.

[10] Diploick, E. E., Mardlin, D. P., Killham, K. S., Paton, G. I. (2009): Predicting bioremediation of hydrocarbons: laboratory to field scale. - Environ. Pollut. 6: 18311840. Available at: 10.1016/j.envpol.2009.01.022.

[11] Ghoreishi, G., Alemzadeh, A., Mojarrad, M., Djavaheri, M. (2017): Bioremediation capability and characterization of bacteria isolated from petroleum contaminated soils in Iran. - Sustainable Environ. Res. 27: 195-202. Available at: http://dx.doi.org/10.1016/j.serj.2017.05.002.

[12] Ghosal, D., Ghosh, S., Dutta, T. K., Ahn, Y. (2016): Current state of knowledge in microbial degradation of polycyclic aromatic hydrocarbons (PAHs): a review. - Front. Microbiol. 7: 1369-1389. Available at: https://doi.org/10.3389/fmicb.2016.01369.

[13] Gong, X. B. (2012): Remediation of weathered petroleum oil-contaminated soil using a combination of biostimulation and modified fenton oxidation. - Int. Biodeterior. Biodegr. 70: 89-95. Available at: 10.1016/j.ibiod.2012.02.004.

[14] Hassanshahian, M., Yakimov, M. M., Denaro, R., Genovese, M., Cappello, S. (2014): Using real-time PCR to assess changes in the crude oil degrading microbial community in contaminated seawater mesocosms. - Int. Biodeterior. Biodegr. 93: 241-248. Available at: https://doi.org/10.1016/j.ibiod.2014.06.006.

[15] INEGI. (2015): Geographical and climatological aspects of Poza Rica, Veracruz. - Basic information notebook for the Mexican population, Mexico.

[16] Karamalidis, A. K., Evangelou, A. C., Karabika, E., Koukkou, A. I., Drainas, C., Voudrias, E. A. (2010): Laboratory scale bioremediation of petroleum-contaminated soil by indigenous microrganims and added Pseudomonas aeruginosa strain Spet. -Biores. Technol. 101: 6545-6552. Available at: 10.1016/j.biortech.2010.03.055. 
[17] Kauppi, S., Sinkkonen, A., Romantschuk, M. (2011): Enhancing bioremediation of diesel-fuel-contaminated soil in a boreal climate: comparison of biostimulation and bioaugmentation. - Int. Biodeterior. Biodegr. 65: 359-368. Available at: https://doi.org/10.1016/j.ibiod.2010.10.011.

[18] Lin, X., Li, X. J., Sun, T. H., Li, P. J., Zhou, Q. X., Sun, L. N., Hu, X. J. (2009): Changes in microbial populations and enzyme activities during the bioremediation of oil contaminated soil. - Bull Environ. Contam. Toxicol 83: 542-547. Available at: https://doi.org/10.1007/s00128-009-9838-x.

[19] Liu, W., Luo, Y., Teng, Y., Li, Z., Ma, L. Q. (2010): Bioremediation of oily sludge contaminated soil by stimulating indigenous microbes. - Environ. Geochem. health 32: 23-29. Available at: https://doi.org/10.1007/s00128-009-9838-x.

[20] Ma, X. K., Ding, N., Peterson, E. C. (2015): Bioaugmentation of soil contaminated with high-level crude oil through inoculation with mixed cultures including Acremonium sp. Biodegradation 26: 259-269. Available at: https://doi.org/10.1007/s10532-015-9732-7.

[21] Milic, J. S., Beskoski, V. P., Ilic, M., Ali, S. A., GojgicCvijovic, G. Đ., VRVIC, M. M. (2009): Bioremediation of soil heavily contaminated with crude oil and its products: composition of the microbial consortium. - J. Serbian Chem. Soc. 74: 455-460. Available at: https://doi.org/10.2298/JSC0904455M.

[22] Nikolopoulou, M., Kalogerakis, N. (2010): Biostimulation strategies for enhanced bioremediation of marine oil spills including chronic pollution. In: Timmis, K. N. (ed.), Handbook of Hydrocarbon and Lipid Microbiology 9: 2521-2529, Springer-Verlag Berlin Heidelberg, Available at: https://doi.org/10.1007/978-3-540-77587-4_187.

[23] Sharma, S. (2012): Bioremediation: features, strategies and applications. - Asian J. Pharm. Life Sci.: 2231-4423. Available at: http://ajpls.com/admin/issues/issue131.pdf.

[24] Silva, I. S., Dos Santos, E. D. C., de Menezes, C. R., de Faria, A. F., Franciscon, E., Grossman, M., Durrant, L. R. (2009): Bioremediation of a polyaromatic hydrocarbon contaminated soil by native soil microbiota and bioaugmentation with isolated microbial consortia. - Bioresour. Technol. 100: 4669-4675. Available at: https://doi.org/10.1016/j.biortech.2009.03.079.

[25] Soares, R. D. C. F., Almeida, D. G., Meira, H. M., Silva, E. J., Farias, C. B. B., Rufino, R. D., Luna, J. M., Sarubbo, L. A. (2017): Production and characterization of a new biosurfactant from Pseudomonas cepacia grown in low-cost fermentative medium and its application in the oil industry. - Biocat. And Agricult. Biotech. 12: 206-215.

[26] Suja, F., Rahim, F., Raihan-Taha, M., Hambali, N., Razali, M. R., Khalid, A., Hamzah, A. (2014): Effects of local microbial bioaugmentation and biostimulation on the bioremediation of total petroelum hydrocarbons (TPH) in crude oil contaminated soil based on laboratory and field observations. - Int. Biodeter. \& Biodegrad. 90: 115-122. Available at: http://dx.doi.org/10.1016/j.ibiod.2014.03.006.

[27] Taccari, M., Milanovic, V., Comitini, F., Casucci, C., Ciani, M. (2012): Effects of biostimulation and bioaugmentation on diesel removal and bacterial community. - Int. Biodeterior. Biodegr. 66: 39-46. Available at: https://doi.org/10.1016/j.ibiod.2011.09.012.

[28] Tindal, M. (2005): Environmentally Acceptable Endpoints for Weathered/Aged Petroleum Hydrocarbon CCME CWS Fraction 3. - Presentation prepared for: 2005 Soil and Groundwater Issues Forum, Petroleum Technology Alliance Canada, March 23, 2005. Calgary, Alberta.

[29] Wu, M. L., Chen, L. M., Tian, Y. Q., Ding, Y., Dick, W. A. (2013): Degradation of polycyclic aromatic hydrocarbons by microbial consortia enriched from three soils using two different culture media. - Environ. Pollut. 178: 152-158. Available at: https://doi.org/10.1016/j.envpol.2013.03.004.

[30] Wu, M., Dick, W. A., Li, W., Wang, X., Yang, Q., Wang, T., Xu, L., Zhang, M., Chen, L. (2016): Bioaugmentation and biostimulation of hydrocarbon degradation and the microbial community in a petroleum-contaminated soil. - Int. Biodeter. \& Biodegrad. 107: 158-164. Available at: http://dx.doi.org/10.1016/j.ibiod.2015.11.019. 